\section{MIIROBBIOLOCI I DN PARASITOLOCI}

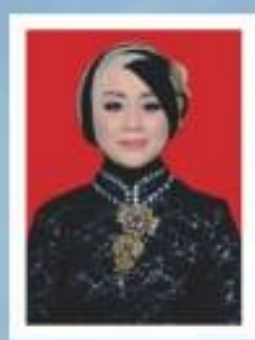

Wahyuni, S.ST, M.Biomed lahir di Bukittinggi, Sumatera Barat pada tanggal 24 Februari 1986. Studi Diploma III (A.Md, Keb) diselesaikan pada Program Studi D.III Kebidanan Bukittinggi Poltekkes Padang bulan April tahun 2018 kemudian melanjutkan Studi Diploma IV (S.ST) pada Program Studi D.IV Bidan Pendidik Poltekkes Kemenkes Padang dan menyelesaikan proses bulan April tahun 2012. Pasca Sarjana(M.Biomed) diselesikan bulan April tahun 2016 pada Program Studi IImu Biomedik Kedokteran Universitas Andalas Peminatan Reproduksi Kedokteran.

Saat ini penulis adalah Dosen tetap pada Universitas Fort De Kock Bukittinggi dan pernah menjadi Tenaga Bidan salah satu rumah sakit yang ada di Kota Bukittinggi tahun 2018-2019, Staff Dosen Kebidanan STIKes Perintis Sumatera Barat tahun 2019-2012 dan Dosen tetap Akademi Kebidanan Pelita Andalas Bukittinggi tahun 2012-2016

Mata kuliah yang di asuh adalah Anatomi dan Fisiologi, Biokimia, Mikrobiologi dan Parasitologi, Asuhan Neonatus Bayi Balita dan Anak PraSekolah, IImu Kesehatan Anak (IKA) serta Asuhan Kebidanan Kegawat Daruratan Maternal dan Neonatal

Selain itu Penulis juga aktif menulis jurnal penelitian dan melaksanakan kegiatan Pengabdian Kepada Masyarakat termasuk kegiatan Organisasi Ikatan Bidan Indonesia (IBI) dan Dharma Wanita (DW).

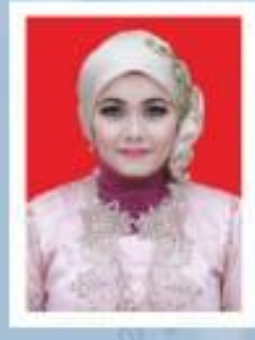

Indrie Ramadhani S. S.Si M.Biomed lahir di Padang, Sumatera Barat pada tanggal 27 April 1989. Studi S1 (S.Si) diselesaikan di Jurusan Biologi Universitas Andalas Padang tahun 2011 dan melanjutkan Studi Pasca Sarjana (M.Biomed) di Program studi Ilmu Biomedik Universitas Andalas Padang, Peminatan Imunologi.

Saat ini penulis merupakan dosen tetap di Akademi Farmasi Dwi Farma Bukittinggi sejak tahun 2013. Mata kuliah dan Praktikum yang di asuh adalah Biologi Farmasi, Ilmu Komunikasi, Ilmu Kesehatan Masyarakat, Praktikum Mikrobiologi dan Praktikum Farmakognosi. Selain itu penulis juga aktif dalam menulis jurnal penelitian dan melakukan Pengabdian Kepada Masyarakat.

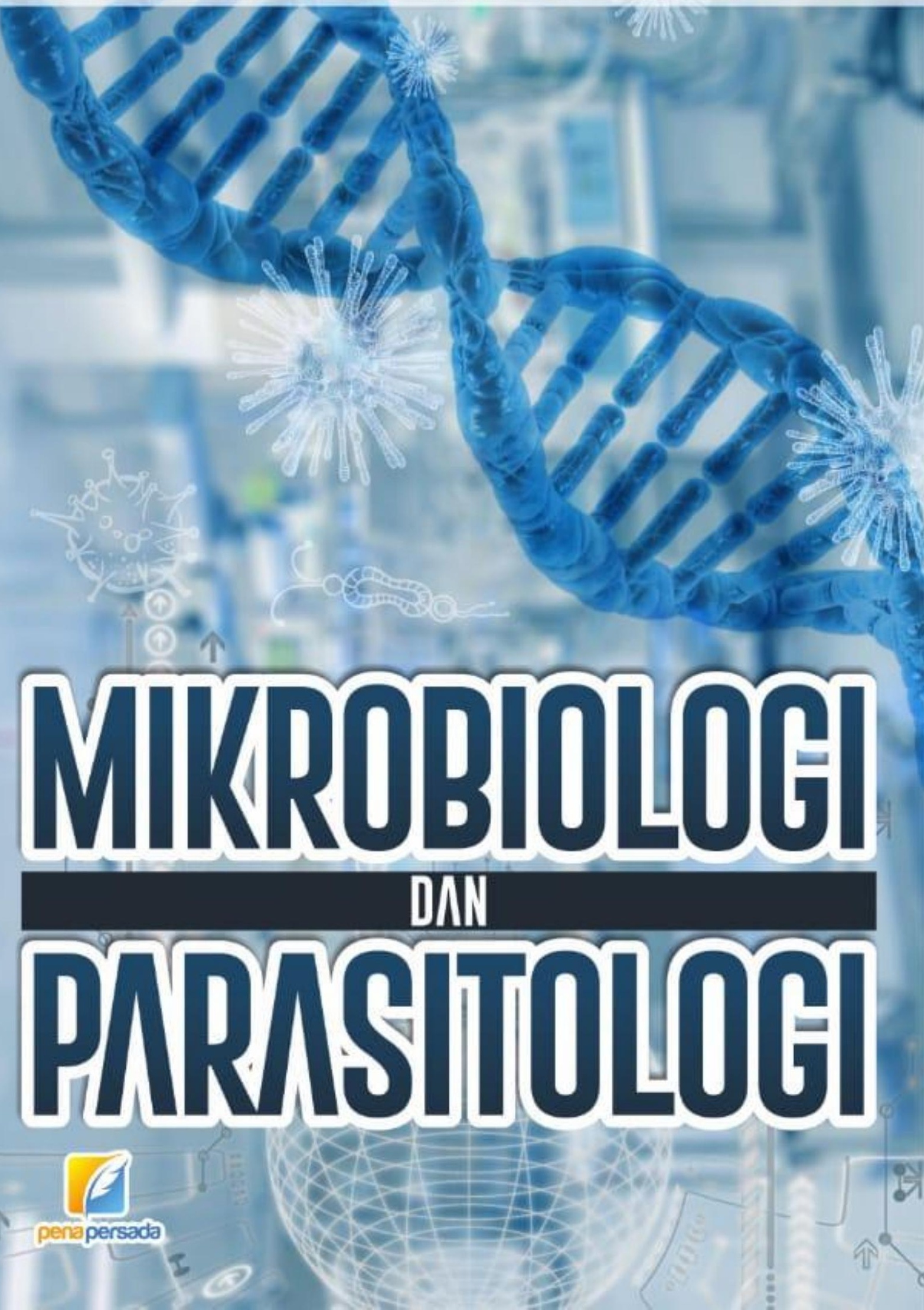




\section{MIKROBIOLOGI DAN PARASITOLOGI}

Wahyuni, S.ST, M.Biomed

Indrie Ramadhani S. S.Si M.Biomed

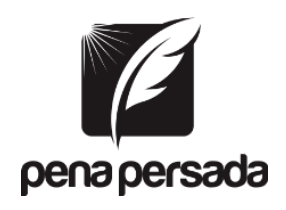

PENERBIT CV. PENA PERSADA 


\title{
MIKROBIOLOGI DAN PARASITOLOGI
}

\author{
Penulis : \\ Wahyuni, S.ST, M.Biomed \\ Indrie Ramadhani S. S.Si M.Biomed \\ ISBN : 978-623-6504-80-2 \\ Editor: \\ Dr. dr. Netti Suharti, M. Kes \\ Desain Sampul : \\ Retnani Nur Briliant \\ Penata Letak : \\ Fajar T. Septiono \\ Penerbit CV. Pena Persada \\ Redaksi : \\ Jl. Gerilya No. 292 Purwokerto Selatan, Kab. Banyumas \\ Jawa Tengah \\ Email : penerbit.penapersada@gmail.com \\ Website : penapersada.com \\ Phone : (0281) 7771388
}

Anggota IKAPI

All right reserved

Cetakan pertama : 2020

Hak Cipta dilindungi oleh undang-undang.

Dilarang memperbanyak karya tulis ini dalam bentuk dan cara apapun tanpa izin penerbit. 


\section{KATA PENGANTAR}

Alhamdulillah atas rahmat Allah SWT sehingga penyusunan Buku Mikrobiologi dan Parasitologi ini dapat diselesaikan dengan baik. Buku ini dibuat sebagai acuan bagi tutor dan menambah ilmu pengetahuan pembaca. Buku ini membahas tentang materi Mikrobiologi dan Parasitologi yang meliputi sejarah dan konsep dasar mikrobiologi, sel, bakterologi, virology, mikologi, nutrisi dan pertumbuhan mikroorganisme, metabolism mikroorganisme, pemeriksaan pada mikrobiologi, peranan mikroorganisme, infeksi dan keragaman mikroorganisme. Saran dan kritikan positif sangat kami harapkan demi kesempurnaan. Terimakasih yang tak terhingga kepada semua pihak yang telah membantu dalam pembuatan buku ini dan semoga dapat bermanfaat bagi semua.

Bukittinggi, Juni 2020

Penyusun 


\section{DAFTAR ISI}

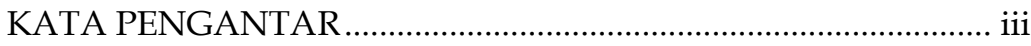

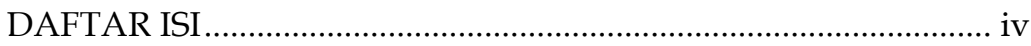

TOPIK 1 :

SEJARAH DAN KONSEP DASAR MIKROBIOLOGI ...................... 1

A. Sejarah Mikrobiologi .............................................................. 1

B. Mikroskop dan Penemuan Dunia Mikroorganisme ........... 2

C. Teori Abiogenesis dan Teori Biogenesis Teori AbiogenesI (Generatio Spontanea) ............................................................. 3

D. Kegagalan Teori Abiogenesis dan Lahirnya Teori

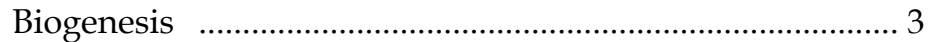

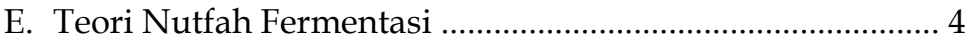

F. Teori Nutfah Penyakit .............................................................. 5

G. Konsep dasar Mikrobiologi dan Aplikasi dalam Bidang

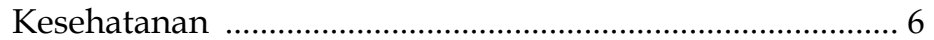

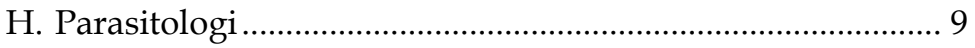

TOPIK 2 :

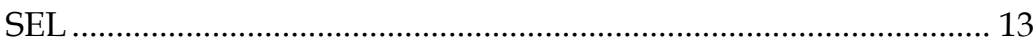

A. Sejarah Penemuan Sel .......................................................... 13

B. Sel Merupakan Kesatuan atau Unit Struktural Makhluk

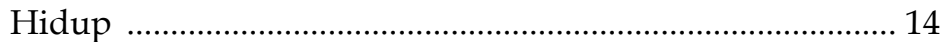

C. Sel Sebagai Unit Fungsional Makhluk Hidup ...................... 14

D. Sel Sebagai Unit Pertumbuhan Makhluk Hidup .................. 14

E. Sel Sebagai Unit Hereditas Makhluk Hidup ........................ 14

F. Penemuan Yang Mendukung Perkembangan Teori Sel .... 15

G. Komponen Kimia Sel ........................................................ 15

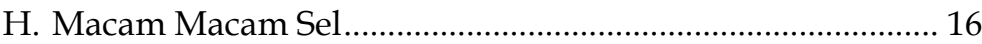

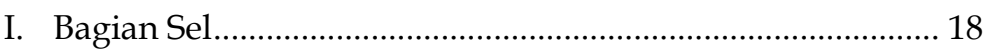

TOPIK 3 :

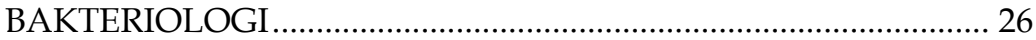

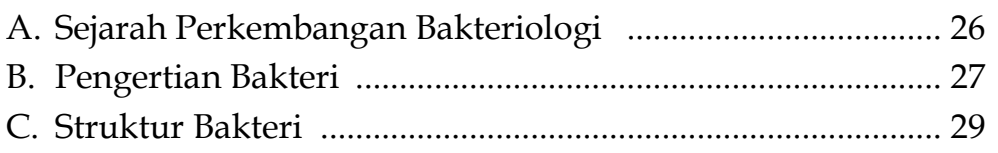




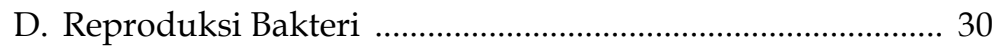

E. Fungsi Serta Peran Bakteri Dalam Kehidupan Manusia .... 32

F. Ciri Ciri Morfologi Bakter ...................................................... 33

G. Morfologi Tumbuhan Coy ……………………………….... 36

\section{TOPIK 4 :}

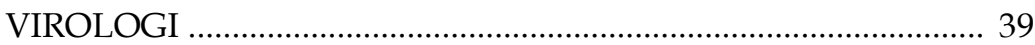

A. Konsep Dasar Virologi ………………………...................... 39

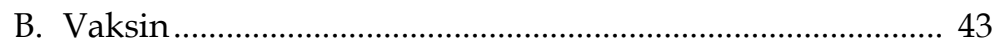

\section{TOPIK 5 :}

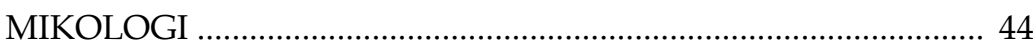

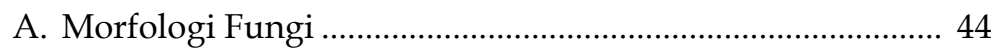

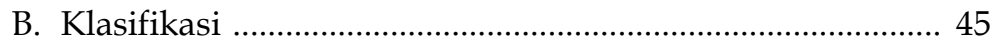

C. Fungi Penyebab sakit .............................................................. 51

TOPIK 6 :

NUTRISI DAN PERTUMBUHAN MIKROORGANISME ............. 53

A. Pengertian Nutrisi................................................................. 53

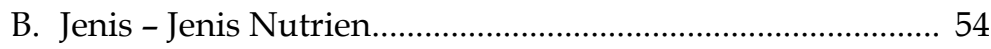

C. Fisiologi Nutrisi dan Metabolisme ......................................... 59

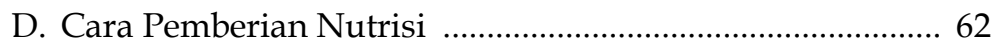

E. Pertumbuhan Mikroorganisme............................................... 64

TOPIK 7 :

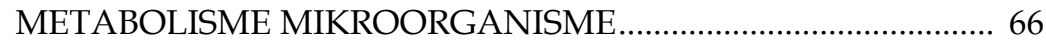

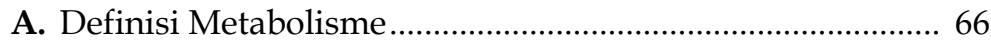

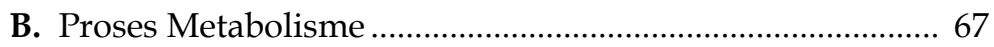

C. Senyawa Pembawa Energi, ATP dan ADP ……………...... 67

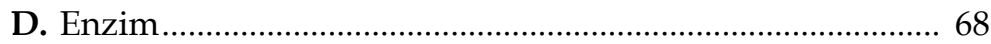

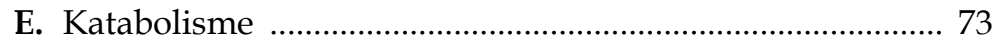

F. Anabolisma : Fotosintesis ……………….......................... 79

TOPIK 8 :

PERANAN MIKROORGANISME_........................................... 82

A. Peran Mikroorganisme dalam Bidang Pangan .................... 82

B. Peran Merugikan Mikroorganisme ....................................... 84 
C. Peran Menguntungkan Mikroorganisme............................... 85

D. Peran Mikroorganisme dalam Bidang Industri.................... 87

E. Peran Mikroorganisme dalam Bidang Pertanian .................. 92

F. Peran Merugikan Mikroorganisme........................................ 92

G. Peran Menguntung Mikroorganisme ................................... 93

TOPIK 9 :

PEMERIKSAAN PADA MIKROBIOLOGI ..................................... 96

A. Media Pertumbuhan Mikroba ............................................... 96

TOPIK 10 :

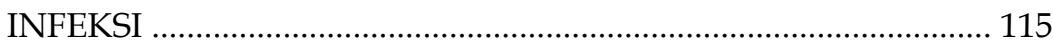

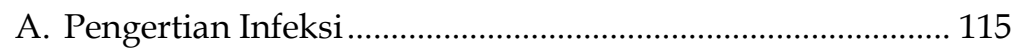

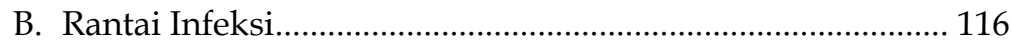

C. Beberapa Agen Yang Dapat Menyebabkan Infeksi .............. 117

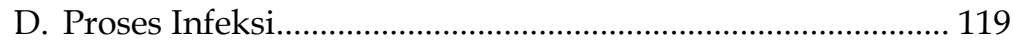

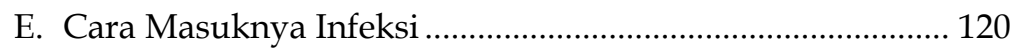

F. Pertahanan Terhadap Infeksi .............................................. 123

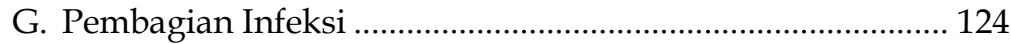

H. Macam Macam Infeksi ........................................................... 124

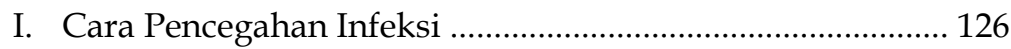

J. Bagan Rantai Infeksi.......................................................... 128

TOPIK 11 :

KERAGAMAN MIKROORGANISME …………........................... 130

A. Pengertian Mikroorganisme ................................................... 130

B. Bakteri Dalam Mikrobiologi Kesehatan …………................. 133

C. Jamur Dalam Mikrobiologi Kesehatan .................................... 136

D. Alga dalam mikrobiologi kesehatan ........................................ 136

E. Protozoa Dalam Mikrobiologi Kesehatan .............................. 137

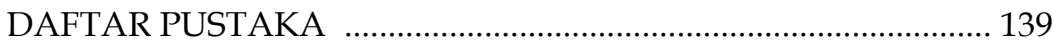

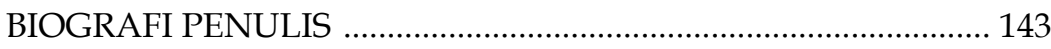


TOPIK 1

SEJARAH DAN KONSEP DASAR MIKROBIOLOGI

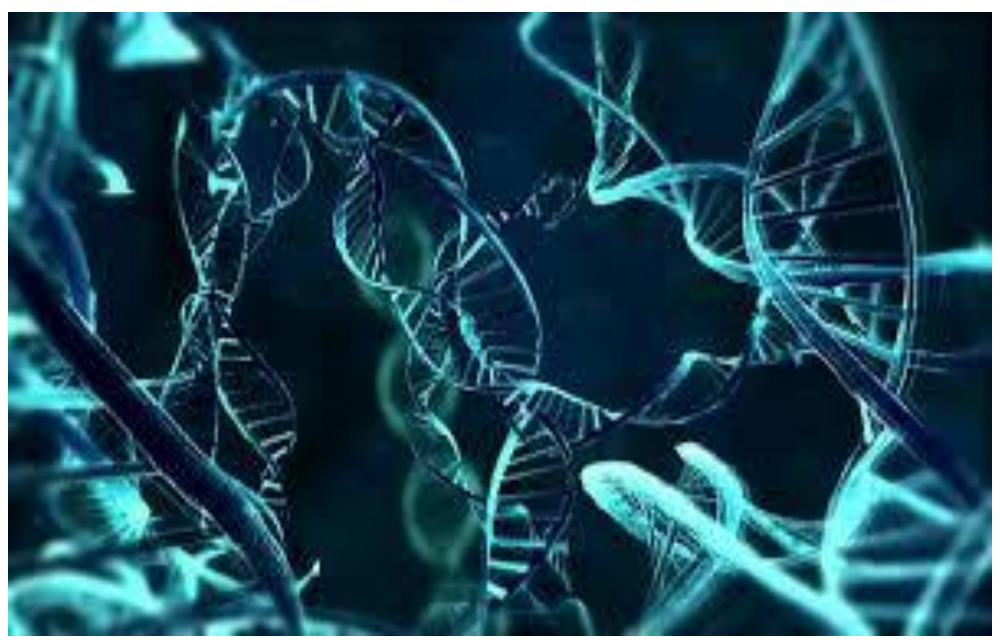

\section{A. Sejarah Mikrobiologi}

Mikrobiologi berasal dari bahasa Yunani yaitu Mikros = kecil, Bios = hidup, dan Logos = ilmu. Secara definitif mikrobiologi adalah suatu ilmu yang mempelajari makhluk hidup yang sangat kecil (diameter kurang dari 0,1 mm) yang tak dapat dilihat dengan mata biasa tanpa bantuan suatu peralatan khusus.

Untuk pertama kalinya organisme tersebut dilihat dan digambarkan kurang lebih 300 tahun yang lalu. Namun demikian, baru pada tahun 1870-an peranannya sebagai penyebab penyakit menjadi dimengerti dan diterima. Mikroorganisme terdapat dalam populasi yang besar dan beragam, dan terdapat hampir di mana-mana di alam ini. Mikroorganisme juga merupakan bentuk kehidupan yang tersebar paling luas dan terdapat paling banyak di planet ini. Mereka terdapat di aliran air, danau, sungai, dan laut. Mereka terdapat pada permukaan tubuh kita dan di dalam mulut, 
hidung, dan rongga $\neg$ rongga tubuh lainnya. Mikroorganisme paling banyak terdapat di tempat $\neg$ tempat yang mengandung nutrient, kelembaban, dan suhu yang sesuai untuk pertumbuhan dan perkembang biakannya.

Di antara mikroorganisme tersebut ada yang bermanfaat bagi kehidupan manusia, tetapi banyak pula yang merugikan yaitu yang dapat menimbulkan berbagai penyakit. Mikrobiologi mempelajari banyak segi mengenai jasad-jasad renik, seperti di mana adanya, ciri-cirinya, kekerabatan antara sesamanya juga dengan kelompok organisme lainnya.

Mikrobiologi meliputi berbagai disiplin ilmu seperti bakteriologi, imunologi, virology, mikologi dan parasitologi. Dalam Mikrobiologi kedokteran, dipelajari mikroorganisme yang ada kaitannya dengan penyakit (infeksi) dan dicari jalan pencegahan, penanggulangan serta pemberantasannya.

\section{B. Mikroskop dan Penemuan Dunia Mikroorganisme}

Antoni van Leeuwenhoek (1632-1723) dari Belanda merupakan orang yang pertama melaporkan pengamatannya dengan keterangan dan gambar-gambar yang teliti. Selama hidupnya ia telah membuat lebih dari 250 mikroskop berlensa tunggal dengan kekuatan pembesaran 200 - 300 kali. Pada tanggal 9 Juni 1675, Leeuwenhoek menulis dalam buku hariannya, "mengumpulkan air hujan dalam cawan", dan pada tanggal 10 Juni ia melanjutkan, "Sambil mengamati air tersebut aku berkhayal bahwa aku menemukan makhluk-makhluk hidup, tetapi karena amat sedikitnya serta tidak terdapati dengan mudah, maka hal ini tak dapat kuterima sebagai hal yang benar". Keesokan harinya kembali melakukan pengamatan dan mencatat, "Tak ada pikiran padaku bahwa akan tampak makhluk hidup, tetapi setelah kuamati maka dengan penuh kagum aku melihat seribu makhluk hidup dalam setetes air. Makhluk hidup itu merupakan jenis terkecil yang pernah kulihat sampai kini". Pada tanggal 17 September 1683, Leeuwenhoek mengamati bakteri dalam suspensi tartar yang dikoreknya dari sela-sela giginya. Ia membuat sketsa sel bakteri 
dengan bentuk bulat (kokus), batang (basilus), dan spiral (spirilum).

\section{Teori Abiogenesis dan Teori Biogenesis Teori AbiogenesI (Generatio Spontanea)}

Berdasarkan penemuan dari Leeuwenhoek tersebut, pada masa itu mereka menganggap bahwa jasad renik (makhluk hidup) berasal dari bahan mati yang mengalami penghancuran. Teori ini dikenal dengan Generatio Spontanea atau abiogenesis, yaitu kehidupan berasal dari benda mati. Teori ini dicetuskan oleh bangsa Yunani Kuno dan bertahan untuk beberapa lama. Pada tahun 1749, John Needham salah satu pendukung abiogenesis melakukan percobaan dengan memasak daging yang terdapat mikroorganisme. Ia berkesimpulan bahwa jasad-jasad renik tersebut berasal dari daging (benda mati).

\section{Kegagalan Teori Abiogenesis dan Lahirnya Teori Biogenesis}

Beberapa tokoh yang menolak teori Abiogenesis adalah :

\section{Lazaro Spallanzani}

(1729 - 1799), ia mendidihkan kaldu daging, yaitu suatu larutan nutrient dalam labu selama satu jam dan ditutup rapat $\urcorner$-rapat, sehingga tidak terdapat jasad renik dalam labu tersebut

2. Franz Schulze (1815 - 1873) mengalirkan udara melewati larutan asam pekat ke dalam labu kaldu daging yang dididihkan. Maka dalam labu tersebut tidak terdapat mikroorganisme karena terbunuh oleh larutan asam tersebut

3. Theodor Schwann (1810 - 1882) melewatkan udara melalui tabung yang membara ke dalam labu berisi kaldu daging yang dididihkan. Maka di dalam labu tersebut tidak terdapat mikroba karena terbunuh oleh panas yang luar biasa

4. Schroder dan von Dusch (1850) melakukan percobaan dengan melewatkan udara melalui tabung berisi kapas ke dalam labu berisi kaldu yang sebelumnya dipanaskan. 
Mikroba disaring ke luar dari udara oleh serat-serat kapas dan dengan demikian dicegah masuk ke dalam labu. Maka tidak terdapat mikroba yang tumbuh dalam kaldu tersebut

5. John Tyndall (1870) menciptakan sebuah kotak bebas debu dan menempatkan tabung-tabung berisi kaldu steril di dalamnya. Selama udara dalam kotak itu bebas debu, maka selam itu pula kaldu dalam tabung tetap steril. partikelpartikel debu mengendap dan tertahan pada tabung berleher angsa yang menuju ke dalam kotak. Inilah bukti bahwa mikroba terbawa oleh partikel-partikel debu

6. Louis Pasteur (1822 - 1895) ahli kimia yang ikut serta dalam menentang teori Abiogenesis. Ia mempersiapkan larutan nutrient dalam labu yang dilengkapi dengan lubang panjang dan sempit berbentuk 'leher angsa'. Kemudian ia memanaskan larutan nutrient itu dan udara dibiarkannya lewat keluar masuk tanpa perlakuan dan tanpa disaring. Tak ada mikroba dalam larutan itu karena partikel-partikel debu yang mengandung mikroba tidak mencapai larutan nutrient dalam tabung dan mengendap di bagian tabung berbentuk huruf $U$

\section{E. Teori Nutfah Fermentasi}

Semenjak jaman purbakala telah banyak dilakukan pembuatan makanan dan minuman yang merupakan hasil fermentasi jasad renik, seperti minuman anggur di Yunani, pembuatan bir di Mesopotamia, bir beras/nasi di Cina, kecap dari kacang di Jepang dan Cina, susu yang difermentasikan di Balkan dan minuman alkohol (koumiss) dari susu unta yang diragikan di Asia Tengah. Pada jaman dahulu, orang memperbaiki mutu produk-produk fermentasinya dengan mencoba-coba. Setelah Pasteur menelaah peranan mikroorganisme dalam fermentasi pada pembuatan anggur maka orang menjadi mengerti bahwa mikroorganisme yang menyebabkan terjadinya fermentasi. Untuk mencapai hasil yang baik, maka mikroba yang sudah ada dalam sari buah harus dihilangkan dan fermentasi yang baru dimulai dengan Biakan, yaitu suatu 
pertumbuhan mikroorganisme yang diambil dari tong anggur yang dinilai baik. Pasteur menyarankan agar menghilangkan tipe $\neg$ tipe mikroba yang tidak diinginkan itu dengan pemanasan dengan suhu $62,80 \mathrm{C}$ selama setengah jam. Hal ini disebut dengan pasteurisasi yang digunakan secara meluas pada industri fermentasi.

\section{F. Teori Nutfah Penyakit}

Fracastoro dari Verona (1546) menyatakan bahwa penyakit dapat disebabkan oleh jasad renik yang terlalu kecil untuk dapat dilihat yang ditularkan dari seseorang ke orang lain.

Von Plenciz dari Vienna (1762) berpendapat bahwa bukan hanya makhluk hidup saja yang dapat menyebabkan penyakit, tetapi juga berbagai jasad renik menimbulkan bermacam-macam penyakit. Konsep parasitisme, yaitu adanya organisme yang hidup pada atau di dalam organisme lain dengan mengambil nutrient dari padanya. Oliver Wendell Holmes (1843) seorang fisikawan dan sastrawan menyatakan bahwa demam nifas itu (demam yang timbul ketika baru melahirkan) yang sering fatal, menular dan boleh jadi disebabkan oleh mikroorganisme yang dibawa oleh bidan dan dokter, dari ibu yang satu kepada yang lain. Ignaz Philip Semmelweis (1840) ahli fisika Hongaria mempelopori penggunaan prosedur obstetric (kebidanan) yang dapat mengurangi kemungkinan infeksi yang disebabkan jasad-jasad renik.

Edward Jenner (1749-1823) menyusun suatu konsep tentang vaksinasi dan berhasil membangkitkan/menimbulkan kekebalan pada orang-orang terhadap cacar (smallpox) denganjalan memvaksinasinya memakai cacar sapi (cowpox). Louis Pasteur (1877) menangani masalah antraks, penyakit pada sapi, domba dan terkadang manusia. Setelah mengamati penyebab penyakit itu darid arah hewan yang mati karena penyakit tersebut, maka ia manumbuhkannya dalam labu-labu di laboratorium. Robert Koch (1870-an) dari Jerman, juga 
menangani masalah antraks. Ia mengisolasi bakteri bentuk batang dengan ujungnya agak persegi (basilus) dari darah biribiri yang mati karena antraks. Ia berhasil mengasingkan kuman antraks dalam bentuk biakan murni (pure culture) dengan mempergunakan medium, dan membuktikan bahwa kuman tersebut dapat menimbulkan penyakit yang sama bila dimasukkan ke dalam tubuh binatang percobaan.

Berdasarkan penemuan tersebut lahirlah Postulat Koch, yaitu:

1. Mikroorganisme tertentu selalu dapat dijumpai berasosiasi dengan penyakit tertentu

2. Mikroorganisme itu dapat diisolasi dan ditumbuhkan menjadi biakan murni di laboratorium

3. Biakan murni mikroorganisme tersebut harus mampu menimbulkan penyakit yang sama pada binatang percobaan

4. Penggunaan prosedur laboratorium memungkinkan diperolehnya kembali mikroorganisme yang disuntikan itu dari hewan yang dengan sengaja diinfeksi dalam percobaan. Kemudian Koch menemukan bakteri yang menimbulkan tuberculosis dan kolera. Pada tahun 1900, semua jenis mikroorganisme penyebab pelbagai penyakit penting telah dapat diketahui seperti Bacillus anthracis, Corynebacterium diptheriae, Salmanolla typhosa, Neisseria gonorrhoeae, Clostridium perfringens, Clostridium tetani, Shigella dysentriae, Treponema pallidum dan lain-lain

\section{G. Konsep dasar Mikrobiologi dan Aplikasi Dalam Bidang Kesehatanan}

Semenjak dipastikannya bahwa jasad renik merupakan penyebab penyakit tertentu, banyak perhatian ditujukan kepada pengembangan cara-cara untuk pencegahan dan pengobatan terhadap penyakit tersebut. Penyebab etiologis (agen kausatif) untuk sebagian besar penyakit bacterial yang dikenal masa kini ditemukan secara berturut-turut dalam waktu singkat antara tahun 1876 dan 1898. Aplikasi mikrobiologi dalam bidang kesehatan terdiri atas ilmu 
pengobatan, yaitu etiologi dan diagnosis penyakit menular, dan kesehatan masyarakat, yaitu cara-cara pengendalian timbulnya dan tersebarnya penyakit. Metode pencegahan dan pengobatan untuk memberantas penyakit karena mikroorganisme meliputi imunisasi (missal vaksinasi), antisepsis (cara-cara untuk meniadakan atau mengurangi kemungkinan infeksi), kemoterapi (perawatan pasien dengan bahan kimia), dan cara-cara kesehatan masyarakat (missal pemurnian air, pembuangan limbah, dan pengawetan makanan). Untuk lebih jelasnya akan di bahas dalam bab tersendiri.

1. Imunisasi

Sekitar 1880 Pasteur mengisolasi bakteri yang menjadi penyebab kolera ayam dan menumbuhkannya pada biakan murni dengan menggunakan teknik-teknik dasar yang dikemukakan Koch. Ia melakukan percobaan demonstrasi di depan masyarakat mengenai prinsip imunisasi pada dua kelompok ayam. Mula-mula ayam-ayam diinokulasi dengan biakan bakteri kolera berumur beberapa minggu dan ayamayam ini tetap sehat. Beberapa minggu kemudian Pasteur menginokulasi ayam-ayam tersebut dengan biakan segar bakteri kolera ayam. Biakan virulen yang segar ini tidak membuat ayam-ayam itu sakit, tetapi membunuh ayamayam yang belum diinokulasi dengan biakan yang teratenuasi (kurang virulen) sebelumnya. Percobaan ini menunjukkan bahwa biakan 'tua' bakteri kolera ayam, sekalipun tidak mampu menimbulkan penyakit, dapat menyebabkan ayam-ayam itu menghasilkan substansi pelindung yang disebut antibodi di dalam darahnya

2. Fagositosis

Dalam waktu yang bersamaan, Elie Metchnikoff (1845-1916) yang bekerja di laboratorium Pasteur, mengamati bahwa leukosit, semacam sel dalam darah manusia dapat memakan bakteri penyebab penyakit yang ada dalam tubuh. pelindung terhadap infeksi ini dinamakan 
fagosit atau "pemakan sel" dan prosesnya disebut fagositosis. Dari pengamatan ini Metchnikoff membuat hipotesis bahwa fagosit merupakan barisan pertahanan pertama yang penting bagi si penderita terhadap mikroorganisme yang menyerbu tubuhnya

\section{Antisepsis}

Sepsis berarti infeksi; antisepsis berkenaan dengan cara-cara pemberantasan atau pencegahan infeksi. Dalam tahun 1864 seorang ahli bedah Inggris, Joseph Lister (1 8271912) mencatat $45 \%$ dari pasiennya meninggal setelah pembedahan. Kemudian ia mencari cara untuk mencegah angka kematian akibat pembedahan yang terinfeksi mikroba, maka Lister menggunakan larutan encer asam karbolat (fenol) untuk merendam perlengkapan bedah dan menyemprot ruang bedah. Kemudian luka dan torehan yang dilindungi dengan cara ini jarang terjadi kena infeksi dan dengan cepat menjadi sembuh. Sekarang banyak sekali macam zat kimia, seperti alkohol dan larutan iodium, dan teknik fisik seperti saringan udara dan lampu ultraviolet germisidal yang digunakan untuk menurunkan jumlah mikroba di kamar bedah dan kamar anak-anak untuk merawat bayi yang prematur

4. Kemoterapi

Paul Ehrlich (1845-1915) ahli fisika Jerman mengembangkan bahan $\neg$ bahan kimia yang dapat membunuh mikroba tanpa merugikan si penderita. Gerhard Domagk (1930) seorang ilmuwan Jerman menemukan sekelompok senyawa sulfonamide (obat sulfa) efektif untuk pengobatan beberapa infeksi oleh bakteri. Pada tahun 1929, Alexander Fleming seorang bekteriologiwan Skotlandia melaporkan hasil penelitiannya tentang suatu substansi yang dihasilkan jamur Penicillium notatum yang menghambat pertumbuhan bakteri pada medium biakan laboratorium. Penisilin adalah antibiotik, 
suatu substansi yang dihasilkan oleh satu mikroorganisme yang dalam jumlah yang sangat kecil dapat menghambat pertumbuhan jasad renik lain. Penemuan penisilin membuka jalan bagi penemuan dan produksi komersial berbagai antibiotik lain

\section{H. Parasitologi}

Kata parasitologi berasal dari kata parasitos yang berarti jasad yang mengambil makanan, dan logos yang berarti ilmu. Berdasarkan istilah, parasitologi adalah ilmu yang mempelajari organisme yang hidup untuk sementara ataupun tetap di dalam atau pada permukaan organisme lain untuk mengambil makanan sebagian atau seluruhnya dari organisme tersebut. Beberapa istilah penting yang perlu diketahui, antara lain :

1. Simbiose, merupakan bentuk hidup bersama dua jenis organisme yang bersifat permanen dan tidak bisa dipisahkan. Ada beberapa jenis simbiose, yaitu :

a. Simbiose mutualisme, yaitu simbiose yang saling menguntungkan bagi kedua jenis organisme tersebut

b. Simbiose komensalisme, yaitu simbiose dimana satu pihak mendapat keuntungan sedangkan yang lain tidak dirugikan

c. Simbiose parasitisme, yaitu simbiose dimana satu jenis mendapatkan makanan dan keuntungan, sedangkan yang lain dirugikan bahkan dibunuh

d. Simbiose obligat, yaitu bentuk simbiose dimana parasitnya tidak dapat hidup tanpa hospes

e. Simbiose fakultatif, yaitu simbiose dimana parasitnya dapat hidup walaupun tanpa hospes

f. Simbiose monoksen, yaitu simbiose dimana parasitnya hanya dapat hidup pada satu spesies hospes

g. Simbiose poliksen, yaitu simbiose yang menghinggapi lebih dari satu spesies

h. Simbiose parasit permanen, yaitu bnetuk simbiose dimana parasitnya selama hidupnya tetap pada hospesnya 
i. Simbiose parasit temporer, yaitu bentuk simbiose dimana parasit pada hospesnya hanya sewaktu-waktu

2. Hospes, yaitu organisme yang merupakan tempat atau organisme yang dihinggapi parasit. Dikenal ada beberapa jenis hospes, yaitu:

a. Hospes defenitif, yaitu hospes dimana terdapat parasit dalam stadium dewasa di dalam tubuh hospes terjadi perkembangbiakan secara seksual

b. Hospes paratenik, yaitu hospes dimana parasit hanya terdapat dalam stadium larva dan tidak dapat berkembang menjadi stadium dewasa dan tidak terjadi perkembangbiakan parasit secara seksual dan parasit ini dapat ditularkan kepada hospes defenitif karena parasit dalam stadium ini merupakan stadium infektif

c. Hospes intermediate (perantara), yaitu hospes dimana parasit di dalamnya menjadi bentuk infektif yang siap ditularkan kepada hospes atau manusia yang lain

d. Hospes reservoir, yaitu hewan yang mengandung parasit yang sama dengan parasit manusia dan dapat menjadi sumber infeksi bagi manusia

e. Hospes obligat, yaitu hospes tunggal yang merupakan satu-satuny spesies yang dapatmenjadi tuan rumah dari parasite dewasa

f. Hospes alternatif, yaitu hospes utama yang mengandung parasit namun ada spesies lain yang dapat sebagai hospes yang mengandung parasite dewasa

g. Hospes insidental, yaitu bila suatu spesies secara kebetulan dapat mengandung parasit dewasa, padahal hospes yang sesungguhnya adalah spesies lain

3. Vektor, yaitu hewan yang di dalam tubuhnya terjadi perkembangbiakan dari parasit, dan parasit itu dapat ditularkan kepada manusia atau hewan lainnya. Biasanya yang berperan sebagai vektor adalah serangga 
4. Zoonosis, yaitu parasit hewan yang dapat ditularkan kepada manusia. Secara umum, pembagian parasit berdasarkan atas jenis parasit tersebut yaitu kelompok tumbuhan atau kelompok binatang. Atas dasar ini parasit dibagi menjadi :

a. Zooparasit, yaitu parasit yang berupa makanan. Zooparasit dibagi menjadi 3 yaitu : protozoa, metazoa (bersel banyak) seperti cacing dan arthropoda (antara lain : serangga)

1) Fitoparasit, yaitu parasit yang berupa tumbuhtumbuhan yang terdiri dari bakteri (dianggap tumbuhan) dan fungi/jamur

2) Spirochaeta dan Virus. Sebagian besar ilmuwan sependapat bahwa kelompok ini tidak dimasukkan ke dalam kelompok binatang atau tumbuhan. Selain pembagian tersebut di atas, parasit dapat dibagi berdasarkan letak atau tempat dimana parasit tersebut hidup.

b. Endoparasit, yaitu jenis parasit yang hidup di dalam tubuh hospes.

c. Ektoparasit, yaitu jenis parasit yang hidup di luar/dipermukaan tubuh hospes.

Parasitologi yang mempelajari hubungan antara manusia dan penyebab kesakitan atau kematian bagi manusia disebut Parasitologi kedokteran (Medical parasitologi). Penyebab kesakitan dan kematian pada manusia tesebut dapat dari protozoa, helminthes (kelompok cacing), arthropoda, fungi (jamur) dan virus. Selain pembagian parasit sebagaimana di atas, klasifikasi parasit dapat berdasarkan jenis organisme parasit, sehingga pembagian parasit sebagai berikut :

1. Protozoa, parasit yang berasal dari protozoa dibagi dalam 4 kelas, yaitu : Sporozoa, Rhizopoda, Flagellata/ Mastighopora, dan Ciliata

2. Helminthes (Helmin atau kelompok cacing), helmintes dibagi menjadi 2 kelas, yaitu : Nemathelmintes,(antara lain Nematoda dan Plathelmintes (termasuk Trematoda dan Cestoda) 
3. Fungi/Jamur

4. Arthropoda. Dimana arthropoda yang penting dalam bidang kesehatan, adalah kelas Hexapoda (insekta) yang terdiri dari 7 ordo 
TOPIK 2

SEL

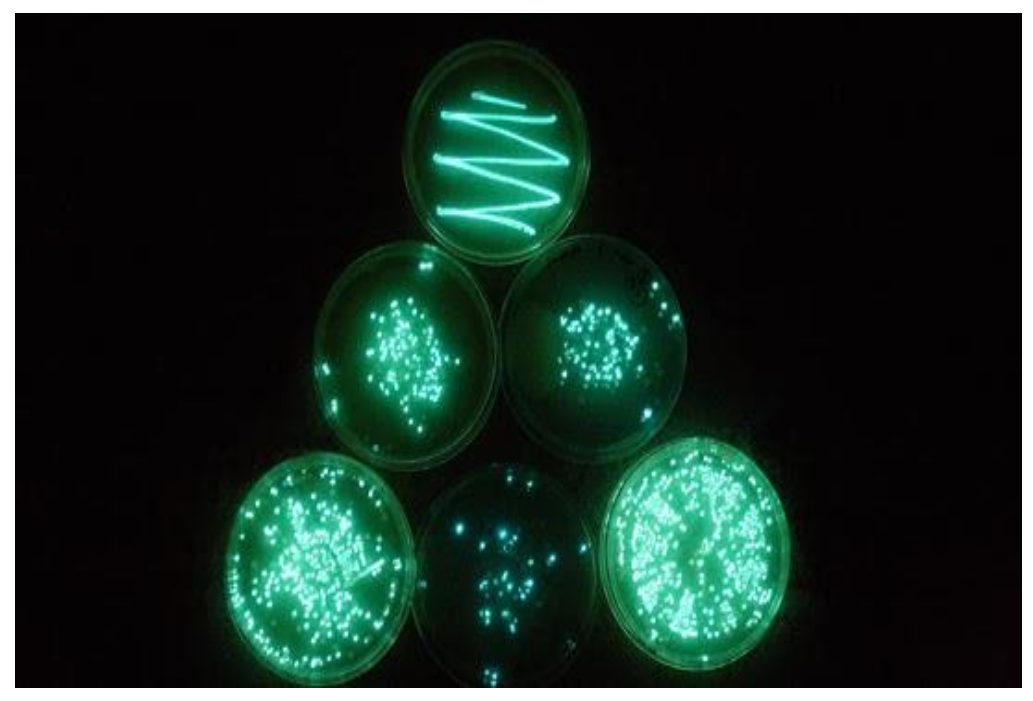

\section{A. Sejarah Penemuan Sel}

Pada tahun 1665, Robert Hooke mengamati sayatan gabus dari batang Quercus suber menggunakan mikroskop. Ia menemukan adanya ruang-ruang kosong yang dibatasi dinding tebal dalam pengamatannya. Robert Hooke menyebut ruang ruang kosong tersebut dengan istilah cellulae artinya sel. Sel yang ditemukan Robert Hooke merupakan sel-sel gabus yang telah mati. Sejak penemuan itu, beberapa ilmuwan berlomba untuk mengetahui lebih banyak tentang sel.

Ilmuwan Belanda bernama Antonie van Leeuwenhoek (1632-1723) merancang sebuah mikroskop kecil berlensa tunggal. Mikroskop itu digunakan untuk mengamati air rendaman jerami. Ia menemukan organisme yang bergerakgerak di dalam air, yang kemudian disebut bakteri. Antonie van Leeuwenhoek merupakan orang pertama yang menemukan sel hidup. 